\title{
Changes in the psysical-chemical composition, total polyphenols and antioxidant activity of fresh celery (Apium graveolens L.) dehydrated by hot air and by lyophilization
}

Narváez-Aldáz, C. and Ordoñez-Araque, R.

\begin{abstract}
SUMMARY
The food industry aims at offering food that provides not only nutritional but also functional properties. Celery has been used for a long time, but its bioactive compounds have remained unknown. The objective of this research is to measure the changes in the physical and chemical characteristics, total polyphenols (TP) and antioxidant activity (AA) after applying hot air dehydration (DA) and lyophilization (LF) with two different cut types: rod-shaped (R) and sliced (S). It was found that dehydration treatments can enhance some characteristics in celery. When comparing the results, the treatment of (LF-S) presented the best characteristics with less water activity, $46 \%$ of total dietary fiberconstituted by $41 \%$ of insoluble fiberand $5 \%$ soluble fibe, $377.69 \mathrm{mg} \mathrm{GAE} / 100 \mathrm{~g}$ in total polyphenol content and an antioxidant activity of $82.17 \mu \mathrm{mol} T E / 100 \mathrm{~g}$. These results allow to conclude that celery is a raw material with functional attributes and that it can be industrialized with dehydration technologies, which will enable a long useful life for its bioactive compounds.
\end{abstract}

Key words: Bioactive compounds; preservation method; gallic acid; Trolox equivalents.

Narváez-Aldáz, C. y Ordoñez-Araque, R. R. 2019. Cambios en la composición físico química, polifenoles totales y actividad antioxidante de apio fresco (Apium graveolens L.) deshidratado por aire caliente y por liofilización. Agriscientia 36 (2): 57-65

\section{RESUMEN}

La industria de alimentos busca que además de propiedades nutricionales, los alimentos otorguen propiedades funcionales. El apio ha sido utilizado desde tiempos inmemoriales pero poco se ha conocido sobre su contenido en compuestos bioactivos. En esta investigación se propuso medir los cambios en las características físico químicas, polifenoles totales (PT) y capacidad 
antioxidante (CA) después de aplicar deshidratación por aire caliente (DA) y liofilización (LF) con dos diferentes tipos de corte, en forma de vara (V) y rebanada $(R)$. Se comprobó que los tratamientos de deshidratación pueden potenciar algunas características en el apio. Al comparar los resultados el tratamiento de (LF-R) presentó las mejores características con menor actividad de agua, $46 \%$ de fibra dietaria total conformada por $41 \%$ de fibra insoluble y $5 \%$ de fibra soluble, 377,69 mg EAG/100g en contenido total de polifenoles y una capacidad antioxidante de 82,17 $\mu \mathrm{mol}$ ET/100g. Estos resultados permiten concluir que el apio es una materia prima con atributos funcionales y se lo puede industrializar con tecnologías de deshidratación, lo que permitirá tener un producto con compuestos bioactivos y larga vida útil.

Palabras clave: Compuestos bioactivos; método de conservación; ácido gálico; equivalentes Trolox.

Narváez-Aldáz, C.: Facultad de Ciencias Agronómicas. Ciencias Agropecuarias, Universidad de Chile, Santiago, Chile. Facultad de Salud y Bienestar. Escuela de Nutrición y Dietética. Universidad Iberoamericana del Ecuador, Quito, Ecuador. Orcid: https://orcid.org/0000-0001-97558980. Ordoñez-Araque, R. Escuela de Gastronomía. Universidad de las Américas, Quito, Ecuador. Facultad de Salud y Bienestar. Escuela de Nutrición y Dietética. Universidad Iberoamericana del Ecuador, Quito, Ecuador. Orcid: https://orcid.org/0000-0003-2381-9003. Correspondence to: roberto.ordonez@udla.edu.ec

\section{INTRODUCTION}

Celery (Apium graveolens L.) is considered a functional food par excellence: its nutritional properties, fiber and bioactive compounds offer a number of proven benefits that prevent the risk of gastrointestinal, coronary and cerebrovascular diseases, as well as hypertension and diabetes. For these reasons, the cultivation of this millennial plant is considered very important worldwide. Its stems and leaves are used as raw material for the production of many processed foods (Liu et al., 2018; Parlak, Çiçek and Blanco-Canqui, 2018).

Some of the main nutrients of celery are potassium, sodium, magnesium, phosphorus, calcium, vitamin C, thiamine, riboflavin and niacin. It also has phenolic compounds: flavonols (apigenin, luteolin, kaempferol) and phenolic acids (caffeic acid, ferulic acid and coumaric acid). The stem concentrates more polyphenols, therefore it can have enzymatic affectations in the presence of oxygen but also, they can stabilize lipid peroxidations when inhibiting several enzymes of the oxidoreductase group (Yao and Ren, 2011; Marszałek, Krzyżanowska, Woźniak and Skapska, 2016).

One of the main methods of food preservation is the application of high temperatures to dehydrate it in order to keep the raw material available for a long time. This is why it is important to analyze the changes in physical-chemical characteristics and in bioactive compounds of fruits and vegetables after undergoing this thermal process. It is particularly important for consumers to have products that maintain their nutritional profile during a long shelf life. To obtain products with these characteristics there are two options: traditional hot air drying and lyophilization (Ordoñez-Araque and Barat, 2017; Berk, 2018; Vélez, Perotti, Hynes and Gennaro, 2019).

During dehydration, there are structural changes at cellular level that cause the reduction of the dimensions of the food due to loss of water. It is important to monitor the moisture content and the water activity to have a correct isothermal process. Dehydration by hot air has been the most widely used around the world but it can bring degradation of nutritional compounds, color, texture and even loss of some thermosensitive phytochemical compounds. The lyophilization method is the best technology that exists in the dried food industry. Its principle is sublimation and allows to have dehydrated food without the alteration of its components. Despite being an advanced technique, this principle was developed in the Inca civilization 700 years ago (Berk, 2018; Vélez et al., 2019).

The objective of this investigation was to analyze 
the changes in the content of phenolic compounds, antioxidant activity and physical-chemical components between raw celery and celery subjected to two types of dehydration: dehydration by hot air and by lyophilization.

\section{MATERIALS AND METHODS}

All the analyses were carried out at the microbiology and food sensory evaluation laboratories of the Institute of Nutrition and Food Technology of the University of Chile.

For the analyses, celery samples of the $A$. graveolens species, sweet variety, were used. Fresh samples were acquired at a local market and they were kept at a temperature of $8{ }^{\circ} \mathrm{C}$ until the moment of the analysis. All steps in the analyses were carried out according to the standards laid down in the post-harvest manual of the Catholic University of Chile.

Celery snacks were prepared in the form of slices and sticks keeping in mind a product that can be marketed, and the possible effects of the type of cut were evaluated. First, the samples were defoliated from the outside to the inside to obtain uniform petioles. As suggested by the research by Waghmare and Annapure (2015), it was disinfected with $50 \mathrm{ppm}$ sodium hypochlorite at $10 \%$ concentration and cuts were made manually; the slices had dimensions of $2 \mathrm{~cm}$ high, $8 \mathrm{~cm}$ long and $3 \mathrm{~cm}$ wide; the rods were cut $4.5 \mathrm{~cm}$ high, 1 $\mathrm{cm}$ long and $0.8 \mathrm{~cm}$ wide. After dehydration, the samples were packed in vacuum polypropylene bags until the analyses began.

\section{Drying by hot air}

Following the recommendations by Karam, Petit, Zimmer, Baudelaire and Scher (2016), about hot air dehydration of fruits and vegetables, the samples were placed on a tray oven, separating rods and slices. The drying tunnel by hot air was set at a temperature of $60{ }^{\circ} \mathrm{C}$ with a speed of $4 \mathrm{~m} / \mathrm{s}$ for 180 minutes, which resulted in a humidity of $6 \% \mathrm{w} / \mathrm{w}$. A previous test was carried out to verify that these parameters apply for celery.

\section{Lyophilization}

The rods and slices were placed separately in plastic containers in a Thermo-Scientific (brand) bio freezer for 8 hours at a temperature of $-80^{\circ} \mathrm{C}$. Then, the samples were transferred to the Operón (brand) lyophilizer for 48 hours at a pressure of 1 mbar and $-55^{\circ} \mathrm{C}$ temperature, as recommended by the equipment manufacturer

\section{Experiment design}

To analyze the type of drying according to the type of cut, a randomized experimental design of divided plots was used. The effect of the main plot was dehydration by hot air and lyophilization and the effect of the subplot was the slice and rod. The samples were coded according to the thermal process: hot air (DA) and lyophilized (LF) and according to the cut: rod (R) and slice (S). Thus 4 treatments were obtained: (DA-R), (DA-S), (LF-R) and (LF-S); 5 repetitions were carried out for each treatment.

\section{Physical and chemical characteristics}

\section{Raw material}

$\mathrm{PH}$ was determined using a Schott Si Analytics potentiometer and soluble solids with an Atago refractometer according to the AOAC 2007 method.

The percentage of humidity was measured with a Precisa (brand) equipment. The sample was placed in the humidimeter tray until having a constant weight with a temperature of $90{ }^{\circ} \mathrm{C}$. A Rotronic Instrument Corp. equipment was used to measure the water activity in order to determine the samples' vulnerability to colonization by microorganisms.

\section{Colour}

Colour was measured with a Minolta reflectance colorimeter and the color space measurement technique CIEL (luminosity); chromatic components $a$ and $b$, were used.

\section{Dietary fiber}

Dietary fiber was measured by the enzymatic method proposed by Yang, Yang, Zhou and Bian (2001) which is based on enzymatic digestion with protease and amyloglucosidase to remove protein and starch and thus determine total dietary fiber, soluble and insoluble.

\section{Total polyphenols}

To adjust the sample, 5 grams of each sample were weighed and homogenized with an Ultraturrax IKA equipment, centrifuged with $20 \mathrm{ml}$ of water and methanol $(20: 80 \mathrm{v} / \mathrm{v})$ at $300 \mathrm{rpm}$ for 15 minutes at $4{ }^{\circ} \mathrm{C}$, filtered with whatman paper 2 and stored in Falcon tubes. For the determination of total polyphenols, the method described by Chen, 
Cheng and Liang (2015) was followed through the Folin-Ciocalteu method: $100 \mu \mathrm{L}$ of the previously obtained extract was added to $200 \mu \mathrm{L}$ of the FolinCiocalteu reagent, left standing for 5 minutes and then $800 \mu \mathrm{L}$ of $\mathrm{Na} 2 \mathrm{CO} 3(700 \mathrm{mM})$ was added. The optical density was measured at $765 \mathrm{~nm}$ in an AsysUvm 340 spectrophotometer. The concentration was expressed in $\mathrm{mg}$ GAE/100g of fresh weight (milligram of gallic acid equivalent).

\section{Antioxidant activity}

The antioxidant activity was determined through the DPPH method according to the Brand-William method described in the research by Luziaand Jorge (2014), $0.25 \mathrm{ml}$ of the extract used in the polyphenol content was diluted with $1 \mathrm{ml}$ of reagent 2, 2'-diphenyl-1-pycrylhydrazyl (DPPH). After 30 minutes the absorbance was measured with a spectrophotometer at $517 \mathrm{~nm}$ and the value was expressed in $\mu \mathrm{mol} \mathrm{TE} / 100 \mathrm{~g}$ of fresh weight (micromoles of Trolox equivalent antioxidant activity).

\section{Statistical Analysis}

The results obtained in the analyses of dehydrated celery were analyzed by means of a randomized design and compared with analysis of variance with SPPS statistical software (SPPS 2001, version 11.0). For significant differences between treatments, the data was subjected to Fisher's multiple comparison test of means (PCM), considering $p \leq 0.05$ as level of significance.

\section{RESULTS AND DISCUSSION}

\section{Dehydration time using a hot air oven}

Figure 1 shows the correlation that exists between the drying of celery in slices and rods. The time in which constant weight was obtained was 180 minutes. There were no differences between the different types of cut. The texture of the celery is the ideal for this type of dehydration. This result can be compared with the Ordóñez-Araque and Pardo-Yoza research (2018), where they performed an experiment to dehydrate borojó, obtaining constant weight at 180 minutes of the experiment. The type of cut did not affect the dehydration, as it happened in the investigation by Defraeye (2017) where there were no significant differences between different types of cut in the dehydrated fruit. The temperature used $\left(60{ }^{\circ} \mathrm{C}\right)$ differs from the investigation by Vallespir, Rodríguez, Eim, Rosselló and Simal (2018) where they dehydrated vegetables at $50^{\circ} \mathrm{C}$ with a speed of $1 \mathrm{~m} / \mathrm{s}$ until constant weight, as they implemented freezing as pretreatment to avoid changes during dehydration, which does not allow high temperatures to be applied.

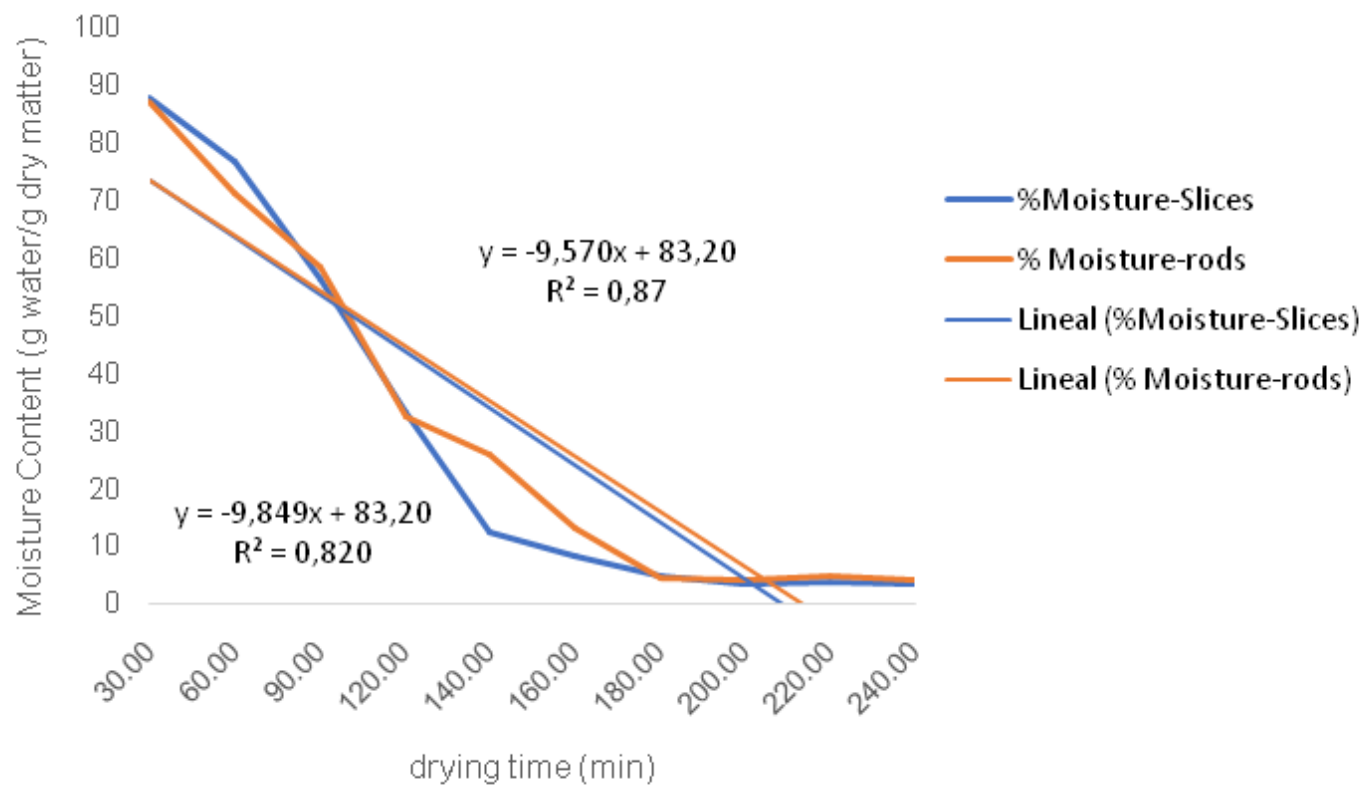

Figure 1. Correlation of hot air-drying curve in celery in slices and rods. 


\section{Physical and chemical characteristics}

\section{pH and soluble solids}

Table 1 shows the results of $\mathrm{pH}$ and soluble solids in celery as a raw material. The results showed a weakly acid to neutral $\mathrm{pH}$ and average soluble solids for this type of vegetables. These values can be compared with research by Qin, Petersen and Bredie (2018) and Kaur, Ghoshal and Jain (2019), who indicate that for the processing of fruits and vegetables it is advisable to use $\mathrm{pH}$ and soluble solids as the two main parameters to manage and industrialize raw material correctly. The values obtained in orange, papaya, carrot and apple juice in these studies were in the same range as the values of celery, which allows to determine that the raw material presented normal characteristics.

\section{Moisture and water activity}

With a humidity of $96 \%$ and water activity of 0.96 it can be established that raw celery is a perishable food and easily susceptible to colonization by different types of microorganisms. The results in celery subjected to thermal treatments indicate that freeze-drying treatment has a greater reduction of moisture content and water activity, which represents a longer shelf life and less probabilities of internal chemical changes in the nutritional and sensory properties of the food (OrdoñezAraque and Barat, 2017). The results obtained are comparable to the investigations by Moussaoui, Bahammou, Idlimam, Lamharrar and Abdenouri (2019) and Tadapaneni, Yang, Carter and Tang (2017), that demonstrate that methods such as lyophilization have better results than conventional drying, obtaining better responses in the modeling of sorption isotherms.

\section{Colour}

Celery as a raw material and dehydrated by hot air has a slight green, yellow and low luminosity tone unlike lyophilized samples that presented a higher luminosity and a greater green and yellow tone. The type of cut did not affect the color under either method. These results are due to the fact that optimized dehydration, such as lyophilization, causes changes in colour, maximizing its nuances and maintaining it during storage for long periods of time. This does not happen only with color, but with several properties, including the stability of probiotic bacteria (Moumita, Das, Hasan and Jayabalan, 2018). These results can be compared with the research by Demirhan and Özbek (2011), who measured the changes that occur in the color of the celery after microwave heating where the luminosity, the green and yellow colors, behaved in the same way as in this investigation with raw celery dehydrated by hot air. The study by Viña, Osornio and Chaves (2007), determined that celery brightness changes according to the type of cut and the type of thermal treatment applied, keeping as a constant an increase in luminosity when excessive temperatures are not applied.

\section{Dietary fiber}

Dietary fiber consists of carbohydrate polymers and oligomers that are digested and fermented completely or partially by the gut microbiota in the small and large intestine. Soluble fiber slows digestion as it retains water and forms gels, while insoluble fiber adds volume to feces and accelerates its passage through the intestine and stomach. These have beneficial health effects such as decreased blood glucose levels, reduced incidence of coronary heart disease and cholesterol, and even prevention of ovarian and colon cancer (Jha, Singh and Prakash, 2017; Xu, Ding, Xin, Wang and Zhang, 2018). The results obtained show a high content of total fiber in dehydrated and lyophilized celery, the fiber represents $40 \%$ of total content, which corresponds to $45 \%$ of the recommended daily intake for adults. These values are superior to those brought out by Pastell, Putkonen and Rita (2019), where they obtained an average of $20 \%$ of total fiber in dried green pea, and that of Pejcz, Czaja, Wojciechowicz-Budzisz, Gil and Spychaj (2017), who made wheat bread enriched with barley with a total fiber content of $10 \%$.

After a thermal process, the degradation of the soluble fiber to smaller fractions and the solubilization of the insoluble fiber can be produced, but the general fiber will always be concentrated, causing the dehydrated product to have a greater fiber contribution than in a natural state (Elleuch et al., 2011).

\section{Total polyphenols}

One of the most important subclasses of plant secondary metabolites are the phenolic compounds. Their chemical structure allows to identify about 8,000 types of polyphenols. They constitute an important part of the human diet. Spectrophotometric methods give quick nonspecific qualitative data on the polyphenol content of food, and its analysis is important to know if that food constitutes a significant source of these compounds (Weber and Passon, 2019). The results obtained in dehydrated and lyophilized celery are interesting for a food that has not been considered an important source of bioactive compounds -furthermore the total phenol content with FolinCicolteau not only made reference to phenols 
because all molecules with redactor power can be positive in this assay, for example glucose. These are well above the values found in the research by Anesini, Ferraro and Filip (2008), VillanuevaTiburcio, Condezo-Hoyos and Asquieri (2010) and Jaiswal, Abu-Ghannam and Gupta (2012). Villanueva-Tiburcio et al. (2010) obtained values between 5 and $7 \mathrm{mg} \mathrm{GAE} / 100 \mathrm{~g}$ in the shell of camucamu (Myrciaria dubia); Anesini et al. (2008) found that black and green tea have a polyphenol content between 8 and $21 \mathrm{mg} \mathrm{GAE} / 100 \mathrm{~g}$; Jaiswal et al. (2012) found through a comparative experiment that extracts of broccoli, brussels sprouts and white cabbage had a total polyphenol amount between 14 and $23 \mathrm{mg}$ GAE/100 $\mathrm{g}$.

As with the total fiber, the content of phenolic compounds is concentrated to a great extent when udergoing thermal processes, but it will depend on the variety of raw material and the technology applied, since it can also decrease its concentration, as in the research by Marszałek et al., (2016) where the celery juice decreased its polyphenols content from 18.83 to $16.01 \mathrm{mg}$ GAE/100g after applying traditional pasteurization at $90{ }^{\circ} \mathrm{C}$ for 10 minutes. Freeze-dried celery has the highest amount of phenolic compounds, its value is high and comparable with most foods that have been studied for their known phenolic profile as in the analysis by Bosanek, Bosanek, Silliman, Kirk and Frankel (1996) with results of 254 to $389 \mathrm{mg} \mathrm{GAE} / 100 \mathrm{~g}$ in commercial grape juices in France, and that by Bunea et al. (2012) where grapes grown conventionally and organically had a concentration between 163 to $1341 \mathrm{mg} \mathrm{GAE} / 100 \mathrm{~g}$.
Another finding is the variation of concentration of compounds between the two types of cut in dehydration by hot air: it is advisable to dehydrate celery in slices to achieve greater concentration of phenolic compounds.

\section{Antioxidant activity}

The antioxidant activity linked to certain bioactive compounds has the ability to break down free radicals avoiding the oxidation of human body cells and alterations in DNA. Fresh celery presented a low antioxidant activity which increased after the dehydration processes because of the concentration of molecules by water elimination. Lyophilization was the treatment with the best results, with an average of $83 \mu \mathrm{mol} T E / 100 \mathrm{~g}$, while the samples dehydrated by hot air had an average of $32 \mu \mathrm{mol} T E / 100 \mathrm{~g}$. The data agrees with the results obtained in the experiment by Yao and Ren (2011) where celery was processed at different cooking temperatures and values achieved varied between 60 and $82 \mu \mathrm{mol}$ TE/100g. The research by Priecina, Karklina and Kince (2018) proves that the longer the celery is exposed to high temperatures, the greater concentration will be obtained in its antioxidant activity. They found that after 1.5 minutes to 3 minutes of exposure to $90{ }^{\circ} \mathrm{C}$, antioxidant activity increased its concentration between 139 to $193 \mu \mathrm{mol} T E / 100 \mathrm{~g}$. Celery has a positive predisposition to increase its antioxidant activity: Zhan et al. (2013) show that it can even increase its concentration when stored with light, in 8 days it can increase up to $164 \%$. Unlike the work by Kamiloglu, Pasli, Ozcelik, Van Camp and Capanoglu (2015),

Table 1. Physical-chemical characteristics, total polyphenols and antioxidant activity in fresh celery, dehydrated by hot air and lyophilized.

\begin{tabular}{|c|c|c|c|c|c|}
\hline \multicolumn{6}{|c|}{ Celery } \\
\hline Characteristics & Fresh & $\begin{array}{l}\text { Hot air } \\
\text { Rod }\end{array}$ & $\begin{array}{l}\text { Hot Air } \\
\text { Slice }\end{array}$ & $\begin{array}{l}\text { Lyophilized } \\
\text { Rod }\end{array}$ & $\begin{array}{l}\text { Lyophilized } \\
\text { slice }\end{array}$ \\
\hline $\mathrm{pH}$ & $6.19 \pm 0.0002$ & - & - & - & - \\
\hline Soluble solids (\%) & $4.55 \pm 0.01$ & - & - & - & - \\
\hline Moisture (\%) & $96 \pm 0.26$ & $6.68 \pm 0.28 a$ & $6.31 \pm 0.38 a$ & $3.77 \pm 0.63 b$ & $3.06 \pm 0.59 b$ \\
\hline Aw & $0.96 \pm 0.002$ & $0.49 \pm 0.003 a$ & $0.39 \pm 0.001 \mathrm{a}$ & $0.27 \pm 0.002 b$ & $0.20 \pm 0.004 b$ \\
\hline \multicolumn{6}{|l|}{ Colour } \\
\hline$L^{*}$ & $28.46 \pm 0.55$ & $36.48 \pm 4.20 \mathrm{a}$ & $34.32 \pm 0.96 a$ & $52.55 \pm 0.69 b$ & $54.30 \pm 1.98 b$ \\
\hline$a^{*}$ & $-11.93 \pm 0.42$ & $-5.63 \pm 0.18 a$ & $-8.00 \pm 1.15 a$ & $-12.14 \pm 1.59 b$ & $-12.78 \pm 1.17 b$ \\
\hline$b$ * & $21.96 \pm 0.16$ & $19, .0 \pm 2.44 \mathrm{a}$ & $18.80 \pm 1.29 \mathrm{a}$ & $22.53 \pm 1.72 b$ & $26.40 \pm 2.59 b$ \\
\hline IDF (g / $100 \mathrm{~g})$ & $35.65 \pm 2.17$ & $41.60 \pm 4.63 a$ & $38.63 \pm 2.05 a$ & $40.75 \pm 4.11 \mathrm{a}$ & $41.59 \pm 4.86 \mathrm{a}$ \\
\hline SDF (g / $100 \mathrm{~g})$ & $3.10 \pm 0.57$ & $4.01 \pm 0.97 \mathrm{a}$ & $4.10 \pm 1.32 \mathrm{a}$ & $3.55 \pm 0.19 a$ & $4.92 \pm 1.19 \mathrm{a}$ \\
\hline TDF (g / 100 g) & $38.75 \pm 2.74$ & $45.61 \pm 5.50 \mathrm{a}$ & $42.73 \pm 2.15 \mathrm{a}$ & $44.30 \pm 4.30 a$ & $46.51 \pm 3.67 \mathrm{a}$ \\
\hline TP (mg GAE / 100 g) & $10.00 \pm 3.25$ & $161.91 \pm 6.25 \mathrm{a}$ & $228.28 \pm 17.81 \mathrm{a}$ & $368.59 \pm 24.67 b$ & $377.69 \pm 16.04 b$ \\
\hline AA $(\mu \mathrm{mol}$ TE / 100g) & $7.31 \pm 6.02$ & $56.97 \pm 14.03 a$ & $46.51 \pm 13.84 a$ & $84.32 \pm 9.38 b$ & $82.19 \pm 9.60 \mathrm{~b}$ \\
\hline
\end{tabular}

The values correspond to the mean \pm standard deviation $(n=5)$. Different lowercase letters in the column indicate statistical difference $\left(p<0.05\right.$, Fisher's PCM). IDF: Insoluble Dietary Fiber; SDF: Soluble Dietary Fiber; TDF: Total Dietary Fiber. L *: Iuminosity; $a^{*}$ : green and red tonalities; $b$ *: yellow and blue tones. TP: Total Polyphenols. AA: Antioxidant Activity. 
where they conducted several industrialization and storage experiments, dehydrated celery had a greater antioxidant activity than the black carrot studied (8 to $54 \mu \mathrm{mol}$ TE/100g) which even had a reduction in its concentration after conventional storage.

\section{CONCLUSIONS}

Celery is a vegetable that presents nutritional and functional components and it can be industrialized by lyophilization or dehydration by hot air for daily consumption. Through this research it was possible to verify its content and to concentrate some of its elements after dehydration processes. It was proved that lyophilization allows a higher concentration of total polyphenols and antioxidant activity than dehydration by hot air, while in soluble, insoluble and total fiber content, the same concentration is maintained with the two treatments. A phenolic compounds profile must be drawn to determine which and in what quantity they are present in order to have more thorough information about its nutritional benefits.

A bioavailability study of the compounds present in celery should be carried out to determine if these are assimilable and to what extent they can benefit consumers. Furthermore, an organoleptic analysis must be performed to study its acceptance among potential consumers.

\section{REFERENCES}

Anesini, C., Ferraro, G. and Filip, R. (2008). Total polyphenol content and antioxidant activity of commercially available tea (Camellia sinensis) in Argentina. Journal of Agricultural and Food Chemistry, 56(19), 9225-9229. doi.org/10.1021/jf8022782

Berk, Z. (2018). Dehydration. En A. M. Clarck (Ed), Food Process Engineering and Technology (Third Edition) (513-566). Haifa, Israel: Academic Press, Elsevier. doi.org/10.1016/B978-0-12-812018-7.00022-1

Bosanek, C., Bosanek, C., Silliman, K., Kirk, L. and Frankel, E. (1996). Total Phenolic Content And Antioxidant Potential Of Commercial Grape Juice. Journal of the American Dietetic Association, 96(9), A35. doi.org/10.1016/S0002-8223(96)00433-6

Bunea, C., Pop, N., Babeş, A., Matea, C., Dulf, F. and Bunea, A. (2012). Carotenoids, total polyphenols and antioxidant activity of grapes (Vitis vinifera) cultivated in organic and conventional systems. Chemistry Central Journal, 6(1), 1-9. doi.org/10.1186/1752153X-6-66
Chen, L., Cheng, C. and Liang, J. (2015). Effect of esterification condensation on the Folin-Ciocalteu method for the quantitative measurement of total phenols. Food Chemistry, 170, 10-15. doi. org/10.1016/J.FOODCHEM.2014.08.038

Defraeye, T. (2017). Impact of size and shape of freshcut fruit on the drying time and fruit quality. Journal of Food Engineering, 210, 35-41. doi.org/10.1016/J. JFOODENG.2017.04.004

Demirhan, E. and Özbek, B. (2011). Color change kinetics of celery leaves undergoing microwave heating. Chemical Engineering Communications, 198(10), 1189-1205. doi.org/10.1080/00986445.2010.525106

Elleuch, M., Bedigian, D., Roiseux, O., Besbes, S., Blecker, C. and Attia, H. (2011). Dietary fibre and fibrerich by-products of food processing: Characterisation, technological functionality and commercial applications: A review. Food Chemistry, 124(2), 411421. doi.org/10.1016/J.FOODCHEM.2010.06.077

Jaiswal, A., Abu-Ghannam, N. and Gupta, S. (2012). A comparative study on the polyphenolic content, antibacterial activity and antioxidant activity of different solvent extracts of Brassica oleracea vegetables. International Journal of Food Science \& Technology, 47(2), 223-231. doi.org/10.1111/j.13652621.2011.02829.x

Jha, S., Singh, H. and Prakash, P. (2017). Dietary fiber and human health: An introduction. En R. A. Samaan (Ed), Dietary Fiber for the Prevention of Cardiovascular Disease (1-22). Los Angeles, CA, United States: Academic Press, Elsevier. doi.org/10.1016/B978-0-12805130-6.00001-X

Kamiloglu, S., Pasli, A., Ozcelik, B., Van Camp, J. and Capanoglu, E. (2015). Colour retention, anthocyanin stability and antioxidant activity in black carrot (Daucus carota) jams and marmalades: Effect of processing, storage conditions and in vitro gastrointestinal digestion. Journal of Functional Foods, 13, 1-10. doi. org/10.1016/i.jff.2014.12.021

Karam, M., Petit, J., Zimmer, D., Baudelaire, E. and Scher, J. (2016). Effects of drying and grinding in production of fruit and vegetable powders: A review. Journal of Food Engineering, 188, 32-49. doi.org/10.1016/J. JFOODENG.2016.05.001

Kaur, P., Ghoshal, G. and Jain, A. (2019). Bio-utilization of fruits and vegetables waste to produce $\beta$-carotene in solid-state fermentation: Characterization and antioxidant activity. Process Biochemistry, 76, 155164. doi.org/10.1016/J.PROCBIO.2018.10.007

Liu, J.-X., Feng, K., Wang, G.-L., Xu, Z.-S., Wang, F. and Xiong, A.-S. (2018). Elevated CO2 induces alteration in lignin accumulation in celery (Apium graveolens L.). Plant Physiology and Biochemistry, 127, 310-319. doi. org/10.1016/J.PLAPHY.2018.04.003 
Luzia, D. and Jorge, N. (2014). Study of antioxidant activity of non-conventional Brazilian fruits. Journal of Food Science and Technology, 51(6), 1167-1172. doi. org/10.1007/s13197-011-0603-x

Marszałek, K., Krzyżanowska, J., Woźniak, Ł. and Skąpska, S. (2016). Kinetic modelling of tissue enzymes inactivation and degradation of pigments and polyphenols in cloudy carrot and celery juices under supercritical carbon dioxide. The Journal of Supercritical Fluids, 117, 26-32. doi.org/10.1016/J. SUPFLU.2016.07.016

Moumita, S., Das, B., Hasan, U. and Jayabalan, R. (2018). Effect of long-term storage on viability and acceptability of lyophilized and spray-dried synbiotic microcapsules in dry functional food formulations. LWT-Food Science and Technology, 96, 127-132. doi. org/10.1016/J.LWT.2018.05.030

Moussaoui, H., Bahammou, Y., Idlimam, A., Lamharrar, A. and Abdenouri, N. (2019). Investigation of hygroscopic equilibrium and modeling sorption isotherms of the argan products: A comparative study of leaves, pulps, and fruits. Food and Bioproducts Processing, 114, 12-22. doi.org/10.1016/J.FBP.2018.11.002

Ordoñez-Araque, R. and Barat, J. (2017). Evaluación de un Sistema de Enmascaramiento de Olor de Muestras de Ajo, Mediante un Sistema de Nariz Electrónica. Revista Politécnica, 40(1), 13-19.

Ordóñez-Araque, R. and Pardo-Yoza, L. (2018). Cuantificación de hierro, calcio y fósforo en procesos térmicos aplicados al borojó (Borojoa patinoi Cuatrec). Idesia, 36, 275-281. doi.org/10.4067/S071834292018005000802

Pastell, H., Putkonen, T. and Rita, H. (2019). Dietary fibre in legumes, seeds, vegetables, fruits and mushrooms: Comparing traditional and semi-automated filtration techniques. Journal of Food Composition and Analysis, 75, 1-7. doi.org/10.1016/j.jfca.2018.09.011

Parlak, M., Çiçek, G. and Blanco-Canqui, H. (2018). Celery harvesting causes losses of soil: A case study in Turkey. Soil and Tillage Research, 180, 204-209. doi.org/10.1016/J.STILL.2018.03.011

Pejcz, E., Czaja, A., Wojciechowicz-Budzisz, A., Gil, Z. and Spychaj, R. (2017). The potential of naked barley sourdough to improve the quality and dietary fibre content of barley enriched wheat bread. Journal of Cereal Science, 77, 97-101. doi.org/10.1016/J. JCS.2017.08.007

Priecina, L., Karklina, D. and Kince, T. (2018). The impact of steam-blanching and dehydration on phenolic, organic acid composition, and total carotenoids in celery roots. Innovative Food Science \& Emerging Technologies, 49, 192-201. doi.org/10.1016/J. IFSET.2018.01.008

Qin, Z., Petersen, M. and Bredie, W. (2018). Flavor profiling of apple ciders from the UK and Scandinavian region. Food Research International, 105, 713-723. doi.org/10.1016/J.FOODRES.2017.12.003

Statistical Program for Social Sciences (SPSS) (version 11.0) [Computer Program] (2001). Chicago, United States: SPSS.

Tadapaneni, R. K., Yang, R., Carter, B. and Tang, J. (2017). A new method to determine the water activity and the net isosteric heats of sorption for low moisture foods at elevated temperatures. Food Research International, 102, 203-212. doi.org/10.1016/J. FOODRES.2017.09.070

Vallespir, F., Rodríguez, Ó., Eim, V., Rosselló, C. and Simal, S. (2018). Freezing pre-treatments on the intensification of the drying process of vegetables with different structures. Journal of Food Engineering, 239, 83-91. doi.org/10.1016/J.JFOODENG.2018.07.008

Vélez, M., Perotti, M., Hynes, E. and Gennaro, A. (2019). Effect of Iyophilization on food grade liposomes loaded with conjugated linoleic acid. Journal of Food Engineering, 240, 199-206. doi.org/10.1016/J. JFOODENG.2018.07.033

Villanueva-Tiburcio, J., Condezo-Hoyos, L. and Asquieri, E. (2010). Antocianinas, ácido ascórbico, polifenoles totales y actividad antioxidante, en la cáscara de camu-camu (Myrciaria dubia (H.B.K) McVaugh). Ciência e Tecnologia de Alimentos, 30, 151-160. doi. org/10.1590/S0101-20612010000500023

Viña, S., Osornio, M. and Chaves, A. (2007). Quality changes in fresh-cut celery as affected by heat treatment and storage. Journal of the Science of Food and Agriculture, 87(7), 1400-1407. doi.org/10.1002/ jsfa.2880

Waghmare, R. and Annapure, U. (2015). Integrated effect of sodium hypochlorite and modified atmosphere packaging on quality and shelf life of fresh-cut cilantro. Food Packaging and Shelf Life, 3, 62-69. doi. org/10.1016/J.FPSL.2014.11.001

Weber, F. and Passon, M. (2019). Characterization and Quantification of Polyphenols in Fruits. En R. R. Watson (Ed), Polyphenols in Plants (Second Edition) (111121). Tucson, AZ, United States: Academic Press, Elsevier. doi.org/10.1016/B978-0-12-813768-0.000074

Xu, H., Ding, Y., Xin, X., Wang, W. and Zhang, D. (2018). Dietary fiber intake is associated with a reduced risk of ovarian cancer: a dose-response meta-analysis. Nutrition Research, 57, 1-11. doi.org/10.1016/J. NUTRES.2018.04.011

Yang, X., Yang, Y., Zhou, R. and Bian, L. (2001). Determination of total, soluble and insoluble dietary fiber in foods by enzymatic-gravimetric method. Journal of Hygiene Research, 30(6), 377-385.

Yao, Y. and Ren, G. (2011). Effect of thermal treatment on 
phenolic composition and antioxidant activities of two celery cultivars. LWT - Food Science and Technology, 44(1), 181-185. doi.org/10.1016/J.LWT.2010.07.001

Zhan, L., Hu, J., Lim, L., Pang, L., Li, Y. and Shao, J.
(2013). Light exposure inhibiting tissue browning and improving antioxidant activity of fresh-cut celery (Apium graveolens var. dulce). Food Chemistry, 141(3), 2473-2478. doi.org/10.1016/j.foodchem.2013.05.035 